
1 2 3 25

\title{
Drought effects on vessel plasticity of two endemic Magnolia species in the tropical montane cloud forests of eastern Mexico
}

4

5 Ernesto Chanes Rodríguez-Ramírez ${ }^{1}$, J. Antonio Vázquez-García ${ }^{2}$, Othón Alcántara-Ayala ${ }^{1}$ (1) and Isolda Luna-Vega ${ }^{1 *}$

(1)

${ }^{1}$ Laboratorio de Biogeografía y Sistemática, Facultad de Ciencias, Universidad Nacional Autónoma de México, Mexico City, Mexico.
${ }^{2}$ Laboratorio de Ecosistemática, Instituto de Botánica, Departamento de Botánica y Zoología, Centro Universitario de Ciencias Biológicas y
Agropecuarias, Universidad de Guadalajara, km 15.5 carr. Guadalajara-Nogales, Camino Ing. Ramón Padilla Sánchez 2100, Nextipac, 45221, Zapopan, Jalisco, Mexico.

${ }^{1 *}$ Corresponding author: luna.isolda@gmail.com, isolda_luna-vega@ciencias.unam.mx

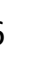

(1)

8

9

20
4 
27 Abstract: The distribution of Mexican Magnolia species' occur under restricted climatic conditions. As many other tree species from the tropical montane cloud forests (TMCF), Magnolia species appear to be sensitive to drought. Through the use of dendrochronological techniques, this study aims to determine the climate influence on the vessel traits of $M$. vovidesii and $M$. schiedeana which are endangered tree species that are endemic to the Sierra Madre Oriental in eastern Mexico. Because most of the tree species in TMCFs are sensitive to climate fluctuations, it is necessary to investigate the differences in the climatic adaptability of the vessel architecture of these trees. This could allow us to further understand the potential peril of climate change on TMCFs. We compared vessel frequency, length and diameter in drought and non-drought years in two Mexican Magnolia species. We used tree-rings width and vessel traits to assess the drought effects on Magnolias' diffuse-porous wood back to the year 1929. We obtained independent chronologies for M. vovidesii with a span of 75 years (1941-2016), while for $M$. schiedeana we obtained a span of 319 years (1697-2016). We found that temperature and precipitation are strongly associated with differences in tree-ring width (TRW) between drought and non-drought years. Our results showed anatomical differences in vessel trait response between these two Magnolia species to climatic variation. We suggest that our approach of combining dendroclimatic and anatomical techniques is a powerful tool to analyse anatomic wood plasticity to climatic variation in Magnolia species.

Keywords: adaptive forestry; dendroecology; diffuse-porous wood; drought years; vessel traits; wood anatomy. 


\section{Introduction}

Tropical montane cloud forests (TMCFs) represent an example of forest ecosystems where direct anthropogenic disturbance and climate change quickly affect the feedback between forests and the hydrological cycle $[1,2]$. These ecosystems are influenced by climate change mainly through the carbon cycle $[3,4]$ and play an important role in the regulation of atmospheric flows, humidity and rainfall recycling, which directly influences local, regional and continental climates [5-7]. Climate fluctuations show that worldwide TMCFs have experienced a warming trend and an increase in elevation of the $0^{\circ} \mathrm{C}$ isotherm during the second half of the $20^{\text {th }}$ century $[1,8]$.

Dendroclimatology is a useful tool that provides past climatic information about the development and ecology of tree species [9-12]. Several studies have confirmed the relationship between climatic seasonality and seasonal growth rings development as a response from tree species. Such a relationship that can be observed in tropical ecosystems with the use of dendrochronology $[11,13,14]$. Climate signals such as precipitation (e.g., rain, mist, fog and cloud water), temperature and/or droughts regulate the growth of TMCFs' tree species $[15,16]$. Dendroecology allows us to identify climatic processes across time and can be used to reconstruct past local and regional climates [9,16,17]. In this context, one of the most important advances in dendrochronological studies has been the additional focus on anatomical features such as vessel traits and/or tree-ring anatomy $[13,18,19]$. For TMCFs' trees, water conduction through the xylem vessels is relevant to understand the effects of stress caused by climatic changes such as those provided by drought years. In particular, plasticity adjustments of the vessel dimensions could be closely related to temperature and precipitation [20,21]. Most of the tree species inhabiting the TMCFs develop reliable and anatomically characteristic annual growth rings 
$73[15,22,23]$. Growth provides trees with the ability to perform anatomical adjustments and since these modifications are, year after year, recorded in growth rings the radial variation of the wood structure along tree-rings can cause hydric and physiological stress [24-27]. This stress usually manifests itself in changes in the anatomy and morphology of the plants (e.g., size, thickness and venation architecture of the leaves, the structure of the xylem vessels, among others), allowing them to survive in unfavorable conditions [22,27].

The genus Magnolia L. belongs to one of the most ancient families of angiosperms (Cretaceous $\approx 50$ to $65 \mathrm{Ma} \mathrm{BP} ;$ [28]) and has a complex biogeographic and climatic history [29]. In Mexico, Magnolia includes 36 species spread into three well supported clades that are considered by several authors as three separate genera: Metamagnolia Sima \& Lu, Magnolia and Talauma Juss. [30,31], treated as sections: Macrophylla Figlar \& Noot., Magnolia and Talauma Juss. [75]. An outstanding 94\% of these species are endemic to Mexico, with a restricted distribution which life forms compose the low and medium strata (7-25 $\mathrm{m}$ high) but can also form a part of the canopy and emergent trees (25-45 $\mathrm{m}$ high). These species coexist with dominant tree species that form the canopy of a wide range of ecosystems, from the Pinus-Liquidambar forest, tropical montane cloud forest, pine-oak tropical subdeciduous forest to the tropical rain forest.

Magnolia vovidesii A. Vázquez, Domínguez-Yescas \& L. Carvajal and M. schiedeana Schltdl. are considered endemic tree species found along the fragmented TMCF range of the Sierra Madre Oriental in eastern Mexico [29]. M. vovidesii belongs to sect. Macrophylla. It is a deciduous and short-lived woody species (e.g. longevity of $M$. macrophylla ca. 50-150 years), mid-successional and shade-tolerant species inhabiting in the Cupressus, Pinus or Liquidambar forests of Central Veracruz. 
On the other hand, M. schiedeana belongs to sect. Magnolia. It is mostly an evergreen and short- to long- lived woody species (e.g., longevity of M. grandiflora of $318 \pm 20$ years), it commonly grows under the canopy of Quercus, Liquidambar, Meliosma, Fagus and Podocarpus [27-29], and is often associated with Ternstroemia, Oreopanax and Styrax. It also occurs in secondary conditions with Alnus and Clethra. This species has a greater morphological variability and a wider distribution, occurring in Hidalgo, Puebla and Veracruz $[71,74]$, ranging from the eastern United States to Mexico and Central America as well as the North of Cuba, it reaches its southern distributional limit at Panamá.

Both species are classified as endangered species under the Red List of Magnoliaceae [56] and the Red List of Mexican cloud forest trees [27-29]. Because both species have very different morphologies and life strategies, it is imperative to research their avility to adapt and resilience to future climate change for conservation planning.

Diffuse-porous wood is an anatomical adaptation that grants a high performance in hydraulic conductance during drought events in TMCFs [32]. Magnolia's wood is mainly characterized as a diffuse-porous wood where xylem vessels maintain the same diameter and are evenly distributed within a growth ring [33,34]. We studied the drought effect on the annual tree-rings width (TRW) of individual trees in two populations of Mexican Magnolia species (M. vovidesii and M. schiedeana; see descriptions in Dieringer and Espinosa [35] and Vázquez-García et al. [36]). Until now, the effects of drought events on vessel plasticity of Magnolia species have not been analyzed. By using dendroclimatic tools, the aim of this study was to determine the influence of past climatic fluctuations, such as years with prevalent drought (here thereafter, drought years) on vessel plasticity of two Mexican magnolias (M. vovidesii and M. schiedeana) with different morphologies and 
119 life strategies. Furthermore, evidence of plasticity changes to the vessel's anatomy during drought years could be used as ecological proxies.

121

\section{Materials and Methods}

\subsection{Study sites}

This study was conducted in two TMCFs located in the Sierra Madre Oriental: (1) El

125 Batda, Huayacocotla, Veracruz (20³3’N, 98²4'W; 1829-1894 m. a.s.l) and Medio Monte, San Bartolo Tutotepec, Hidalgo (20²4’N, 98¹4’W; 1840-1876 m. a.s.1) (Figure 1A-C). In these two sites, Magnolia populations typically occur on steep slopes or ravines. The two sites share a temperate climate $(\mathrm{Cb})$ sensu García [37], characterized by mild temperatures $\left(14.5-24.4^{\circ} \mathrm{C}\right)$. Humidity levels are found in the range of $60-90 \%$ [38]. The soil of the sites is Humic (Th) andosols [39] with light sandy-clay loam texture.

El Batda is located on slightly rugged terrain and is characterized by trees that reach up to $25 \mathrm{~m}$ in height. The forest is dominated by Liquidambar styraciflua L., Pinus patula Schltdl. \& Cham., P. greggii Engelm. ex Parl, and several oak species such as Quercus meavei Valencia-A., Sabás \& Soto, Q. delgadoana S. Valencia, Nixon \& L. M. Kelly. and Q. trinitatis Trel. The mid-canopy of the forest is mainly composed of Magnolia vovidesii, Clethra mexicana DC., Befaria aestuans L. and Podocarpus matudae Lundell, whereas the low-canopy consists mainly of several tree fern species (Cyathea fulva (M. Martens \& Galeotti) Fée, Cyathea bicrenata Liebm., Dicksonia sellowiana var. arachneosa Sodiro and Alsophila firma (Baker) D.S. Conant).

Medio Monte's TMCF's canopy stratum is characterized by trees that reach between $30-45 \mathrm{~m}$ in height. The forest is dominated by several oak species such as Quercus delgadoana, Q. trinitatis and Q. meavei, as well as Magnolia schiedeana, Pinus patula, 
143 Liquidambar styraciflua and rarely Ulmus mexicana (Liebm.) Planch., this last one as an

144

145

146

147

148

149

150

151

152

153

154

155

156

157

158

159

160

161 emergent tree ( $\geq 80 \mathrm{~m}$ ). In some places, Fagus grandifolia subsp. mexicana (Martínez) A.E. Murray is part of the canopy stratum. The mid-canopy of the forest is mainly composed of Befaria aestuans, Clethra mexicana, while the low-canopy consists mainly of Cyathea fulva, Dicksonia sellowiana var. arachneosa and Alsophila firma.

\subsection{Sampling, processing and anatomical measurements}

For each site, we extracted two wood cores from 20 individual magnolia trees with a diameter at breast height $(\mathrm{DBH}) \geq 20 \mathrm{~cm}$, at breast height $(1.3 \mathrm{~m})$ with the use of a Häglof borer. Wood cores were air-dried at room temperature, glued onto wooden supports, and sanded with successive coarse-grit sandpapers 100 and 360 and four finer-grit sandpapers $(400,600,1000$ and 1200) until the xylem's cellular structure was distinguishable with at most a $100 \mathrm{x}$ amplification [9]. Tyloses and wood dust inside vessel lumina were removed with heat by using a hair-dryer. In order to obtain a high contrast between xylem vessels of diffuse-porous and background wood, the vessels were filled with white chalk $[20,40,41]$.

We measured TRW series using a stereoscopic microscope (Olympus SZ61) to the nearest $0.001 \mathrm{~mm}$ for each tree-ring, with the TSAP-Win v. 4.67c program and Velmex tree-ring measuring system (Velmex, Inc., Bloomfield NY, USA). Additionally, we verified the cross-dating with the software COFECHA $[42,43]$. We used the Northern Hemisphere criteria [44-46] to date our tree-ring series and assigned every ring the year in which growth started. False tree-rings were detected through re-examination and comparison between wood cores and a cross-section from fallen trees to correct the chronologies from each site $[15,47]$. 
167

168

169

170

171

172

173

174

175

176

177

178

179

180

181

182

183

\subsection{Analysis of chronologies}

Growth-related trends were removed using a cubic spline with $50 \%$ response of 10 year periods, flexible enough to maximize high-frequency climatic information and minimize the non-climatic variance, such as the age-size related trends and the effects of the stand dynamics $[10,15,48]$. We achieved chronologic quality according to standard dendrochronological procedures [10]. Autoregressive modeling was performed on each standardized series to remove temporal autocorrelation [49] in order to maximize the climatic signal using the ARSTAN computer program [50]. To produce a standardized chronology, the resulting indexed series were averaged using a bi-weight mean to decrease the influence of outliers [51]. Temporal autocorrelation in chronologies is common because of the residual impact of growing conditions from previous years [52].

\subsection{Climatic-growth relationships}

For each site, we compared variation in the chronologies to the mean minimum and mean maximum temperatures $\left(\mathrm{T}_{\min }\right.$ and $\left.\mathrm{T}_{\max }\right)$ and monthly precipitation $(\mathrm{P})$ directly from nearby weather stations (Huayacocotla, Veracruz; 20.5 N, -98.5 W; and Tenango de Doria, Hidalgo; 20.3 N, -98.2 W). More specifically, the CLICOM (http://clicom-mex.cicese.mx/) database was only used for the periods comprising the years of 1961-2015 (Huayacocotla) and 1941-2015 (Tenango de Doria), which were complemented with data from INIFAP weather stations (http://clima.inifap.gob.mx/) for the years 2016-2017 (Figure 1B).

Climate-growth relationships were computed as Pearson's correlation coefficients between the chronologies and climate records $\left(\mathrm{T}_{\max }, \mathrm{T}_{\min }\right.$, and $\left.\mathrm{P}\right)$. The significance level of 
189 the correlations followed the bootstrap technique [53]; for this, we performed 10,000

190 iterations for each coefficient and implemented the correction proposed by Mason and

191 Mimmack [54] to obtain the percentile bootstrap confidence intervals.

192

193

194

195

\subsection{Drought effects on vessel traits}

To assess whether or not drought years have an effect on the plasticity of vessel traits (frequency, length and diameter) of the Magnolia species studied, we selected a subset of 15-18 wood cores to take tree-ring digital images for drought years. We obtained recorded drought events from Climate Data (http://sala.lab.asu.edu/research/drought-net/) [55] (e.g., 1929-30, 1940, 1963, 1970, 1972, 1976, 1983, 1991, 1997, 2012 and 2015-16). We also

followed this procedure for two consecutive years before and two years after El Niño Southern Oscillation events (ENSO). Wood core digital images were captured using a stereoscopic microscope (Leica Z16 APOA) with a 12.9 to $50.3 \mu \mathrm{m}$ field of depth. Images were taken with a digital camera (Leica DFC 490) and saved as TIFF format with a $1.3 \mu \mathrm{m}$ resolution. From both Magnolia species studied, a total of 216 digital images were taken (108 for each one).

For each wood core digital image, we quantified and manually measured all the vessel features using the software Image J [56] by means of the VesselJ plugging (GarcíaGonzález, not published). The correct recognition of all vessels was often hindered by the detection of dust spots or other undesired objects, which were manually excluded, retaining only the objects larger than $10,000 \mu \mathrm{m}^{2}$, and that had a width smaller than twice their length. Vessel outlines were improved by applying morphological operations (erode-dilate $2 \times 2$ one pass, and calculation of the convex hull). 
We performed a multiple comparison Tukey test to assess whether the values of vessel traits (frequency, length, and diameter) present a significant difference between drought years (DY) and non-drought years (NDY) for the Magnolia species studied. These analyses were performed in R (version 3.5.1) using the R-package ggplot2 (https://cran.rproject.org/web/packages/ggplot2/ggplot2.pdf [57]).

\section{Results}

\subsection{Tree-ring width chronologies}

The cross-dated chronology of Magnolia vovidesii we gathered shows a span of 75 years (1941-2016), while for M. schiedeana we obtained a span of 319 years (1697-2016). The chronologies index also showed a distinct inter-annual variation pattern for the Magnolia species studied, except for those tree-rings developed in strong drought years such as 1929-30, 1940, 1963, 1970, 1972, 1976 (Figure 2), 1983, 1991, 1997, 2012 and 2015-16. Correlations among chronologies were strongly significant in all cases. In Medio Monte, mean TRW varied between 0.032 and $2.12 \mathrm{~mm}$ for M. schiedeana, while in El Batda the mean TRW range was 0.456 and $3.02 \mathrm{~mm}$ for M. vovidesii (Table 1). Signal-tonoise ratio (SNR) and the mean between-trees correlation was high in the Magnolia species studied, suggesting a strong common signal is expressed as climate effect on growth rates (Table 1). Mean sensitivity of Magnolia schiedeana was higher compared to M. vovidesii in the chronologies studied. There is a larger relative change between consecutive rings for non-drought years (NDY) than that for drought years (DY) between Magnolia species studied (Figure 2, Table 1).

\subsection{Response to climate}


Correlations with mean maximum temperature $\left(\mathrm{T}_{\max }\right)$ were positive in previous Jan $(-1)$ (see Figure 3) (i.e. late Winter and early Spring (January to February)) and during the dry cool season (Oct (-1) to Nov (-1)) before tree-ring development. A negative correlation occurred in previous Sep (-1), Dec (-1) for radial growth chronology, and current late Spring and Summer (March to June). This drought-sensitive growth dynamics that are supported in the literature for the genus Magnolia worldwide [36,58-60]. The observed correlations between previous dry-cool season from Oct (-1) to Jan (-1) monthly precipitation $(\mathrm{P})$ and growth season were positive in all cases, and mainly during the long cool Summer (June to September) were linked to higher growth ring indices, particularly in El Batda site (Figure 3).

Regarding $\mathrm{T}_{\min }$ in early February to May, these were also negatively associated with the growing season in both study sites. El Batda showed the highest correlation value $(r=0.41)$ from May (dry warm season) to July (long cool summer) (three months). Medio Monte presented low correlation values $(r=0.30)$ for June and July and had 4-month droughts (January, February, June, and July) (Figure 3).

\subsection{The effect of climate on vessel anatomy}

We measured a total of 12,582 vessels traits (8,334 for Magnolia vovidesii and 4,248 for M. schiedeana) in 15-18 wood core digital images (see the climate effect on vessel traits section). On average, for each annual tree-ring the cores contained 9.44 vessels for $M$. vovidesii and 4.81 for $M$. schiedeana. The vessels of $M$. vovidesii are larger and more recurrent than those found in M. schiedeana. Regardless, vessel frequency, length and diameter distribution between DY and NDY (Figure 4) showed strong differences between the two Magnolia species. Vessel frequency was dissimilar between Magnolia species (M. 
260

261

262

263

264

265

266

267

268

269

270

271

272

273

274

schiedeana, ranges from 1-3 for DY and 1-12 in NDY; and M. vovidesii, ranges from 1-14 for DY and 1-20 in NDY; Figure 4A). The vessel diameter ranges from 45 to 181 in $M$. vovidesii, and from 12 to 180 in M. schiedeana (Figure 4B). A similar range of variations has been found for vessel diameter in DY and NDY between Magnolia species (Figure 4C). This variability influences the annual variability of the further derived hydraulic features.

\section{Discussion}

Our findings reveal that the Magnolia species we studied annually generate TRWs that are suitable to assess tree radial growth rate, age and their plasticity regarding climate fluctuations. The dendroecological tools allowed us to evaluate the drought effects on vessel anatomy of diffuse-porous wood up-to the year of 1929. We found evident differences in the vessel hydraulic architecture when comparing DY to NDY and between the two Magnolia species studied (Figure 3 and Figure 4). We argue that such disparities in the present modifications to the vessel traits are due to species-specific physiological plasticity in response to DY. Several studies suggest that recent ENSO events (from 1929 to 2016) pushed the TMCFs' tree species to their anatomical and physiological limits $[11,24,61]$. Our results demonstrate that the Magnolia's vessel traits show a perceptible trend to become less in number and smaller in size during drought periods (Figure 3).

Our results suggest that droughts could not only affect Magnolia species' resilient ability to adapt to long drought-periods but also restrict them from remaining as a part of the TMCFs' structure. For instance, Magnolia schiedeana is a frequent element in Mexican beech forests $[15,62]$, this could indicate a historical dependency to the specific microclimatic conditions given by this forest type that are essential to its establishment and 
283 survival [58,59]. Strong vessel plasticity from M. schiedeana, given drought events (Figure

284 4), enhances the statement of its need for specific microclimatic. Rodríguez-Ramírez et al.

285 [32] found that Mexican beech trees develop similar vessel trait adjustments, which may

286 indicate that this forest type may be very sensitive to drought and thus susceptible to

287 climate change $[17,63,64]$. On the other hand, $M$. vovidesii appears to show resilience to

288 climatic variations such as strong DY, this is seen as a response to climatic variations such

289 as strong DY (Figure 4). The relationship between vessel traits and drought events (Figure

290 4) reflects that both Magnolia species are capable to effectively allocate carbon during high

291 hydric stress. These anatomical adjustments can allow Mexican trees of diverse functional

292 types to continue growth during Fall, even if they are evergreen, semi-deciduous or

293 deciduous trees $[22,32,61,65,66]$.

Rivers et al. [58] and Vazquez-Morales et al. [36] mentioned that Magnolia species that inhabit disturbed fragments of the TMCF could be vulnerable to climate variations. Our study confirms that at the anatomical level, these types of analyses allow us to interpret the vulnerability of the Magnolia species. As such, we suggest that dendroecological and anatomic methods are useful to assess the effect of drought events on Magnolia species worldwide and to evaluate their vulnerability of certain trees to climatic stress $[9,24,35,58,60,61]$. On the hindsight, evaluating just these characteristics can not explain in its entirety the differences observed in TMCFs' trees' hydraulic conducting patterns and vessel functions $[4,19,22]$.

In this study, Magnolia species' TRWs showed the most significant correlation to $\mathrm{T}_{\max }$ 304 and $\mathrm{T}_{\min }$ during March and June, negatively influencing the growth rates of $M$. schiedeana 305 since tree ring growth starts in February. Maximum radial growth rates occur in September 
306 when humidity is higher, but rapidly decrease in November and December. We found a

307 positive response between radial growth and monthly precipitation $(\mathrm{P})$. Only during the

308

309

310

311

312

313 months of-November, -December and January we found that the absence of a continuous rainfall unfavorable for growth in both Magnolia species. This result can be related to the end of the growth period in the TMCFs caused by a dry-cold season. An alternative explanation is that from November to January there is a lack water availability at midelevation stands. At higher stands (>1840 m. a.s.1) Magnolia vovidesii can also be found, usually coexisting with Pinus patula, P. greggii, Liquidambar styraciflua and several oak species, such as Quercus meavei and Q. trinitatis. In preserved areas, $M$. vovidesii has been suggested to be significantly more resistant than M. schiedeana to drought periods.

Possibly, M. schiedeana has been affected by the microclimatic conditions of the Mexican beech forest structure (Fagus grandifolia subsp. mexicana, Q. delgadoana, Q. meavei and Q. trinitatis, and several tree fern species) and/or possible high genetic structure, affecting its climatic resilience [62]. We believe that there are specific climatic factors affecting TRWs' growth rates allowing the individual trees to adapt to these climatic fluctuations.

Opposed to this, from June to -September precipitation showed the opposite effect (Figure 3), precipitation had a positive impact on TRW's growth rates in both species having an even greater benefit on growth rates of $M$. vovidesii.

Our analyses revealed that a great variability in vessel's anatomy of diffuse-porous wood from the two Magnolia species studied is related to temperature and/or water availability. These anatomical adaptations result from a strong reduction in vessel frequency, length and diameter during DY compared to NDY, plastic adaptations that play an important role in water transport and safety [67]. We state that wood plasticity is 
329 essential to identifying climate adaptability of trees in TMCFs. Our findings support that $M$. 349 others. schiedeana is probably more sensitive to drought events than $M$. vovidesii due to poorer vessel structure when confronted against these types of climatic events (Figure 4). Our wood core digital images results demonstrate that most vessel traits show (i) high plasticity from DY to NDY, and (ii) that there are differences in the diffuse-porous wood anatomy and vessel plasticity of the different Magnolia species inhabiting the TMCFs (Figure 4). We deduce that drought induces increased hydraulic conductance with the consequence of high construction costs but reduced hydric transport efficiency and lower TRW growth rates (Figure 3 and 4) [13,24]. Within the growing season of a DY, drought events can potentially induce several xylem architecture modifications at the end of Summer when TMCF trees might merely respond by early ceasing tree-ring formation $[15,22,24]$. The features of the vessel traits, such as wall thickness, arrangement, frequency, diameter and length, among others, are not the only factors involved in the reduced efficiency of the hydraulic systems $[20,68,69]$ but also prevailing climatic conditions. Adaptive responses to the loss of hydraulic conductivity result from the adjustments in the vessel anatomy of diffuse-porous wood that is required to adapt to new environmental requirements $[18,21,69]$. Similar responses have also been reported for different tree species such as Fagus grandifolia subsp. mexicana in Mexico [32], several oak species, such as Quercus cerris L., Q. pubescens Willd. Rita [70], Q. canariensis Willd [61] and Q. pyrenaica Steven in Spain [41], Tectona grandis L. f. and Pinus caribaea Morelet in Brazil [13], among

During DY, it is unlikely that drought-induced cavitation occurred within most vessels, this is because many vessels in the outermost annual ring of all diffuse-porous wood 
352 species maintain their water transport functioning during the growing season

$353[13,25,27,64,71,72]$. In a TMCF, drought could affect which tree species prevail over time,

354 perhaps creating less favorable conditions for trees with relatively harder wood and

355 coriaceous leaves such as Magnolia schiedeana, which present a higher vulnerability to

356 drought conditions than the lusher species that contribute to canopy cover such as $M$.

357 vovidesii.

358 We conclude that our results on specific vessel traits can provide information of the

359 functional costs and benefits of the vessel hydraulic adjustment. This research contributes

360 to a better understanding of the plasticity that occurs in xylem architecture as one of several

361 strategies adopted by the TMCF trees (i.e. rainfall recycling and cooling $[3,6,73]$ ) when

362 exposed to the several effects of climate change

Acknowledgments: We thank Doroteo San Juan for his support during fieldwork. Carlos

Solís Hay for his critical observations and for improving the English style.

Author Contributions: Conceptualization, E.C.R.R., I.L.V., O.A.A., and J.A.V.G; Format postdoctoral fellowship CONACYT 2018-2019. 


\section{References}

1. Watanabe, M.; Shiogama, H.; Tatebe, H.; Hayashi, M.; Ishii, M.; Kimoto, M. Contribution of natural decadal variability to global warming acceleration and hiatus. Nat. Clim. Chang. 2014, 4, 893-897, doi:10.1038/nclimate2355.

2. Hu, J.; Riveros-Iregui, D.A. Life in the clouds: are tropical montane cloud forests responding to changes in climate? Oecologia 2016, 180, 1061-1073, doi:10.1007/s00442-015-3533-x.

3. Price, M.F.; Gratzer, G.; Duguma, L.A.; Kohler, T.; Maselli, D.; Romeo, R. Mountain forests in a changing world: realizing values, addressing challenges.; FAO/MPS and SDC: Rome, 2011; pp. 1-83; ISBN 9789251070765.

4. Locatelli, B.; Catterall, C.P.; Imbach, P.; Kumar, C.; Lasco, R.; Marín-Spiotta, E.; Mercer, B.; Powers, J.S.; Schwartz, N.; Uriarte, M. Tropical reforestation and climate change: beyond carbon. Restor. Ecol. 2015, 23, 337-343, doi:10.1111/rec.12209.

5. Ponce-Reyes, R.; Reynoso-Rosales, V.H.; Watson, J.E.M.; Vanderwal, J.; Fuller, R. A.; Pressey, R.L.; Possingham, H.P. Vulnerability of cloud forest reserves in Mexico to climate change. Nat. Clim. Chang. 2012, 2, 448-452, doi:10.1038/nclimate1453.

6. van Noordwijk, M.; Bruijnzeel, S.; Ellison, D.; Sheil, D.; Morris, C.; Sands, D.; Gutierrez, V.; Cohen, J.; Sullivan, C.A.; Verbist, B.; Murdiyarso, D.M.; Gaveau, D. Ecological rainfall infrastructure: investment in trees for sustainable development. ASB Policy Br. 2015, 47, 6.

7. Ellison, D.; Morris, C.E.; Locatelli, B.; Sheil, D.; Cohen, J.; Murdiyarso, D.; Gutierrez, V.; van Noordwijk, M; Creed, I.F.; Pokorny, J.; Gaveau, D.; Spracklen, 
400

401

402

403

404

405

406

407

408

409

410

411

412

413

414

415

416

417

418

419

420

421

422

D.V.; Tobella, A.B.; Ilstedt, U.; Teuling, A.J.; Gebrehiwot, S.G.; Sands, D.C.;

Muys, B.; Verbist, B.; Springgay, E.; Sugandi, Y.; Sullivan, C.A. Trees, forests and water: cool insights for a hot world. Glob. Environ. Chang. 2017, 43, 51-61, doi:10.1016/j.gloenvcha.2017.01.002.

8. Malhi, Y.; Gardner, T.A.; Goldsmith, G.R.; Silman, M.R.; Zelazowski, P. Tropical forests in the Anthropocene. Annu. Rev. Environ. Resour. 2014, 39, 125-159, doi:10.1146/annurev-environ-030713-155141.

9. Speer, J.H. Fundamentals of tree-ring research; University of Arizona Press: USA, 2010; pp. 1-509; ISBN 978-0-8165-2684-0.

10. Dittmar, C.; Elling, W. Dendroecological investigation of the vitality of common beech (Fagus sylvatica L.) in mixed mountain forests of the Northern Alps (South Bavaria). Dendrochronologia 2007, 25, 37-56, doi:10.1016/j.dendro.2007.01.003.

11. Schöngart, J.; Bräuning, A.; Barbosa, A.C.M.C.; Lisi, C.S.; Oliveira, J.M.

Dendroecological studies in the neotropics: History, status and future challenges.;

Springer, Cham.: Switzerland, 2017; pp. 1-400; ISBN 978-3-319-61668-1.

12. Takashi, K.; Okuhara, I. Comparision of climatic effects on radial growth of evergreen broad-leaved trees at their northern distribution limit and co-dominating deciduous broad-leaved trees and evergreen conifers. Ecol. Res. 2012, 27, 125-132, doi:10.1007/s1 1284-011-0879-3

13. Venegas-González, A.; Chagas, M.P.; Anholetto C.R.; Alvares, C.A.; Roig, F.A.; Filho, T.M. Sensitivity of tree ring growth to local and large-scale climate variability in a region of southeastern Brazil. Theor. Appl. Climatol. 2016, 123, 233-245, doi:10.1007/s00704-014-1351-4. 
14. Worbes, M.; Fichtler, E. Amazonian floodplain forests: Ecophysiology, biodiversity and sustainable management.; Springer Dordrecht Heidelberg, London, 2011; pp. 1 615, doi:10.1007/978-90-481-8725-6.

15. Rodríguez-Ramírez, E.C.; Luna-Vega, I.; Rozas, V. Tree-ring research of Mexican beech (Fagus grandifolia subsp. mexicana) a relict tree endemic to eastern Mexico. Tree-Ring Res. 2018, 74, 94-107, doi:10.3959/1536-1098-74.1.94.

16. Granato-Souza, D.; Adenesky-Filho, E.; Barbosa, A.C.M.C.; Esemann-Quadros, K. Dendrochronological analyses and climatic signals of Alchornea triplinervia in subtropical forest of southern Brazil. Austral Ecol. 2018, 1-12, doi:10.1111/aec.12576.

17. Zell, J. Climate sensitive tree growth functions and the role of transformations. Forests 2018, 9, 382, doi:10.3390/19070382.

18. García-González, I.; Fonti, P. Selecting earlywood vessels to maximize their environmental signal. Tree Physiol. 2006, 26, 1289-1296, doi:10.1093/treephys/26.10.1289.

19. Fonti, P.; Heller, O.; Cherubini, P.; Rigling, A.; Arend, M. Wood anatomical responses of oak saplings exposed to air warming and soil drought. Plant Biol. 2013, 15, 210-219, doi:10.1111/j.1438-8677.2012.00599.x.

20. Fonti, P.; von Arx, G.; García-Ggonzález, I.; Sass-Klaassen, U. Studying global change through investigation of the plastic responses of xylem anatomy in tree rings research. New Phytol. 2010, 185, 42-53, doi:10.1111/j.1469-8137.2009.03030.x. 21. von Arx, G.; Kueffer, C.; Fonti, P. Quantifying plasticity in vessel grouping Added value from the image analysis tool ROXAS. IAWA J. 2013, 34, 433-445, doi:10.1163/22941932-00000035. 
22. Osazuwa-Peters, O.L.; Wright, S.J.; Zanne, A.E. Linking wood traits to vital rates in tropical rainforest trees: Insights from comparing sapling and adult wood. Am. J. Bot. 2017, 104, 1464-1473, doi:10.3732/ajb.1700242.

23. Ohsawa, M. Structural comparison of tropical montane rain forests along latitudinal and altitudinal gradients in south and east Asia. Plant Ecol. 1991, 97, 1-10, doi:10.1007/bf00033897.

24. Rita, A.; Cherubini, P.; Leonardi, S.; Todaro, L.; Borghetti, M. Functional adjustments of xylem anatomy to climatic variability: Insights from long-term Ilex aquifolium tree-ring series. Tree Physiol. 2015, 35, 817-828, doi:10.1093/treephys/tpv055.

25. Pandey, S.; Carrer, M.; Castagneri, D.; Petit, G. Xylem anatomical responses to climate variability in Himalayan birch trees at one of the world's highest forest limit. Perspect. Plant Ecol. Evol. Syst. 2018, 33, 34-41, doi:10.1016/j.ppees.2018.05.004.

26. Liang-Jun, Z.; Zong-Shan, L.; Wang, X.C. Anatomical characteristics of xylem in tree rings and its relationship with environments. Chinese J. Plant Ecol. 2017, 41, 238-251, doi:10.17521/cjpe.2016.0198.

27. Tombesi, S.; Frioni, T.; Poni, S.; Palliotti, A. Effect of water stress "memory" on plant behavior during subsequent drought stress. Environ. Exp. Bot. 2018, 150, 106114, doi:10.1016/J.ENVEXPBOT.2018.03.009.

28. Graham, A. Studies in neotropical paleobotany II: The Miocene communities of Veracruz, Mexico. Ann. Mo. Bot. Gard. 1976, 63, 787-842, doi: 10.2307/2395250 
29. Azuma, H.; García-Franco, J.G.; Rico-Gray, V.; Thien, L.B. Molecular phylogeny of the Magnoliaceae: the biogeography of tropical and temperate disjunctions. Am. J. Bot. 2001, 88, 2275-2285, doi:10.2307/3558389.

30. Vázquez-García, J.A. Taxonomy of the genus Magnolia (Magnoliaceae) in Mexico and Central America. M.S, Dissertation. University of Wisconsin-Madison, USA, 1990.

31. Vazquez-G, J. A. Magnolia (Magnoliaceae) in Mexico and Central America: A Synopsis. Brittonia 1994, 46, 1, doi:10.2307/2807454.

32. Rodríguez-Ramírez, E.C.; Terrazas, T.; Luna-Vega, I. The influence of climate on the masting behavior of Mexican beech: growth rings and xylem anatomy. Trees 2018, 1-13, doi:10.1007/s00468-018-1755-3.

33. Latte, N.; Lebourgeois, F.; Claessens, H. Increased tree-growth synchronization of beech (Fagus sylvatica L.) in response to climate change in northwestern Europe. Dendrochronologia 2015, 33, 69-77, doi:10.1016/j.dendro.2015.01.002.

34. Wróblewska, M.M. The progressive and ancestral traits of the secondary xylem within Magnolia clad-the early diverging lineage of flowering plants. Acta Soc. Bot. Pol. 2015, 84, 87-96, doi:10.5586/asbp.2014.028.

35. Dieringer, G.; Espinosa, J.E. Reproductive ecology of Magnolia schiedeana (Magnoliaceae), a threatened cloud forest tree species in Veracruz, Mexico. Bull. Torrey Bot. Club. 1994, 121, 154-159.

36. Vázquez-García, J. A.; Domínguez-Yescas, R.; Pedraza-Ruiz, R.; SánchezGonzález, A.; Muñiz-Castro, M.Á. Magnolia rzedowskiana (Magnoliaceae), una especie nueva de la sección Macrophylla de la parte central de la Sierra Madre Oriental, México. Acta Botánica Mex. 2015, 112, 19-36. 
37. García, E. Modificaciones al Sistema de Clasificación Climática de Köppen; CONABIO: Mexico, 1988; pp. 1-90; ISBN 970-32-1010-4.

38. Williams-Linera, G.; Toledo-Garibaldi, M.; Hernández, C.G. How heterogeneous are the cloud forest communities in the mountains of central Veracruz, Mexico? Plant Ecol. 2013, 214, 685-701, doi:10.1007/s11258-013-0199-5.

39. FAO (Food and Agricultural Organization of the United Nations). Soil map of the world: revised legend. World soil resources report 60. 1998. Available online: http://faostat.fao.org (accessed on 18 October 2018).

40. Gärtner, H.; Nievergelt, D. The core-microtome: A new tool for surface preparation on cores and time series analysis of varying cell parameters. Dendrochronologia 2010, 28, 85-92, doi:10.1016/j.dendro.2009.09.002.

41. Souto-Herrero, M.; Rozas, V.; García-González, I. A 481-year chronology of oak earlywood vessels as an age-independent climatic proxy in NW Iberia. Glob. Planet. Change 2017, 155, 20-28, doi:10.1016/j.gloplacha.2017.06.003.

42. Holmes, R.L. Computer-assisted quality control in tree-ring dating and measurement. Tree-Ring Bull. 1983, 43, 69-78, doi:10.1016/j.ecoleng.2008.01.004. 43. Grissino-Mayer, H.D. Evaluating crossdating accuracy: A manual and tutorial for the computer program COFECHA. Tree-Ring Res. 2001, 57, 205-221.

44. Rozas, V.; Le Quesne, C.; Muñoz, A.; Puchi, P. Climate and growth of Podocarpus salignus in Valdivia, Chile. Dendrobiology 2016, 76, 3-11, doi:10.12657/denbio.076.001.

45. Stokes, M.A.; Smiley, T.L. An introduction to tree-ring dating; University of Arizona Pres, USA, 1996; pp. 1-73; ISBN 978-0816516803. 
516

517

518

519

520

521

522

523

524

525

526

527

528

529

530

531

532

533

534

535

536

537

538

539

46. Rozas, V. Detecting the impact of climate and disturbances on tree-rings of Fagus sylvatica L. and Quercus robur L. in a lowland forest in Cantabria, Northern Spain. Ann. For. Sci. 2001, 58, 237-251, doi:10.1051/forest:2001123.

47. Haghshenas, M.; Mohadjer, M.R.M.; Attarod, P.; Pourtahmasi, K.; Feldhaus, J.; Sadeghi, S.M.M. Climate effect on tree-ring widths of Fagus orientalis in the Caspian forests, northern Iran. Forest Sci. Technol. 2016, 12, 176-182, doi:10.1080/21580103.2016.1144542.

48. Gareca, E.E.; Fernández, M.; Stanton, S. Dendrochronological investigation of the high Andean tree species Polylepis besseri and implications for management and conservation. Biodivers. Conserv. 2010, 19, 1839-1851, doi:10.1007/s10531-0109807-z.

49. Box, G.E.P., Jenkins, G.M. Time series analysis: forecasting and control; HoldenDay, San Francisco, CA, USA, 1976; pp. 1-712; ISBN 978-1-118-67502-1.

50. Cook E.R.; Holmes, R.L. Guide for computer program ARSTAN. In The international tree-ring data bank program library version 2.0.; Grissino-Mayer, H.D., Holmes, R.L., Fritts H.C.; Laboratory of tree-ring research, Tucson, AZ, USA, 1996; pp. 75-87.

51. Cook, E.R. A time series analysis approach to tree-ring standardization. Ph. D, Dissertation, University of Arizona, Tucson, AZ, USA, 1985.

52. Speer, J.H.; Bräuning, A.; Zhang, Q. Bin; Pourtahmasi, K.; Gaire, N.P.; Dawadi, B.; Rana, P.; Dhakal, Y.R.; Acharya, R.H.; Adhikari, D.L.; Adhikari, S.; Aryal, P.C.; Bagale, D.; Baniya, B.; Bhandari, S.; Dahal, N.; Dahal, S.; Ganbaatar, N.; Giri, A.; Gurung, D.B.; Khandu, Y.; Maharjan, B.; Maharjan, R.; Malik, R.A.; Nath, C.D.; Nepal, B.; Ngoma, J.; Pant, R.; Pathak, M.L.; Paudel, H.; Sharma, B.; Hossain, M. 
540

541

542

543

544

545

546

547

548

549

550

551

552

553

554

555

556

557

558

559

560

561

S.; Soronzonbold, B.; Swe, T.; Thapa, I.; Tiwari, A. Pinus roxburghii stand dynamics at a heavily impacted site in Nepal: Research through an educational fieldweek. Dendrochronologia 2017, 41, 2-9, doi:10.1016/j.dendro.2016.01.005.

53. Guiot, J. The bootstrapped response function. Tree-Ring Bull. 1991, 51, 39-41.

54. Mason, S.J.; Mimmack, G.M. The use of bootstrap confidence intervals for the correlation coefficient in climatology. Theor. Appl. Climatol. 1992, 45, 229-233, doi:10.1007/BF00865512.

55. Lemoine, N.P.; Sheffield, J.; Dukes, J.S.; Knapp, A.K.; Smith, M.D. Terrestrial precipitation analysis (TPA): A resource for characterizing long-term precipitation regimes and extremes. Methods Ecol. Evol. 2016, 7, 1396-1401, doi:10.1111/2041$210 X .12582$.

56. Schneider, C.A.; Rasband, W.S.; Eliceiri, K.W. NIH Image to Image J: 25 years of image analysis. Nat. Methods 2012, 9, 671-675, doi:10.1038/nmeth.2089.

57. Hintze, J.L.; Nelson. R.D. Violin plots: a box plot-density trace synergism. Am. Stat. 1998, 52, 181-184.

58. Rivers, M.; Beech, E.; Murphy, L.; Oldfield, S. The red list of Magnoliaceae revised and extended; Botanical Gardens Conservation International, UK, 2016; pp. 1-60; ISBN 9781905164646.

59. Vásquez-Morales, S.G.; Téllez-Valdés, O.; Pineda-López, D.R.M.; SánchezVelásquez, L.R.; Flores-Estevez, N.; Viveros-Viveros, H. Effect of climate change on the distribution of Magnolia schiedeana: A threatened species. Bot. Sci. 2014, 92, 575-585, doi:10.17129/botsci.116. 
562

563

564

565

566

567

568

569

570

571

572

573

574

575

576

577

578

579

580

581

582

583

584

585

60. Vázquez-García, J.A.; Neill, D.A.; Asanza, M.; Pérez, A.J.; Arroyo, F.; DahuaMachoa, A.; Merino-Santi, R.E. Magnolias de Ecuador: en riesgo de extinción. Universidad Estatal Amazónica, Puyo, 2016a; pp. 1-66; ISBN 978-9942-932-18-1

61. Gea-Izquierdo, G.; Fonti, P.; Cherubini, P.; Chaar, H.; Cañellas, I. Xylem hydraulic adjustment and growth response of Quercus canariensis Willd. to climatic variability. Tree Physiol. 2012, 32, 401-413, doi:10.1093/treephys/tps026.

62. Rodríguez-Ramírez, E.C.; Sánchez-González, A.; Ángeles-Pérez, G. Relationship between vegetation structure and microenvironment in Fagus grandifolia subsp. mexicana forest relicts in Mexico. J. Plant Ecol. 2018, 11, 237-247, doi:10.1093/jpe/rtw138.

63. Kon, H.; Noda, T. Experimental investigation on weather cues for mast seeding of Fagus crenata. Ecol. Res. 2007, 22, 802-806, doi:http://dx.doi.org/10.1007/s11284006-0320-5.

64. Choat, B.; Brodribb, T.J.; Brodersen, C.R.; Duursma, R.A.; López, R.; Medlyn, B. E. Triggers of tree mortality under drought. Nature 2018, 558, 531-539, doi:10.1038/s41586-018-0240-x.

65. Slik, J.W.F.; Franklin, J.; Arroyo-Rodríguez, V.; Field, R.; Aguilar, S.; Aguirre, N.; Ahumada, J.; Aiba, S.I.; Alves, L.F.; K, A.; Avella, A.; Mora, F.; Aymard, G.A.C.; Báez, S.; Balvanera, P.; Bastian, M.L.; Bastin, J.F.; Bellingham, P.J.; van den Berg, E.; da Conceição Bispo, P.; Boeckx, P.; Boehning-Gaese, K.; Bongers, F.; Boyle, B.; Brambach, F.; Brearley, F Q.; Brown, S.; Chai, S.L.; Chazdon, R.L.; Chen, S.; Chhang, P.; Chuyong, G.; Ewango, C.; Coronado, I.M.; Cristóbal-Azkarate, J.; Culmsee, H.; Damas, K.; Dattaraja, H.S.; Davidar, P.; DeWalt, S.J.; Din, H.; Drake, D.R.; Duque, A.; Durigan, G.; Eichhorn, K.; Eler, E.S.; Enoki, T.; Ensslin, A.; 
Fandohan, A.B.; Farwig, N.; Feeley, K.J.; Fischer, M.; Forshed, O.; Garcia, Q.S.; Garkoti, S.C.; Gillespie, T.W.; Gillet, J.F.; Gonmadje, C.; Granzow-de la Cerda, I.; Griffith, D.M.; Grogan, J.; Hakeem, K.R.; Harris, D.J.; Harrison, R.D.; Hector, A.; Hemp, A.; Homeier, J.; Hussain, M.S.; Ibarra-Manríquez, G.; Hanum, I.F.; Imai, N.; Jansen, P.A.; Joly, C.A.; Joseph, S.; Kartawinata, K.; Kearsley, E.; Kelly, D.L.; Kessler, M.; Killeen, T.J.; Kooyman, R.M.; Laumonier, Y.; Laurance, S.G.; Laurance, W.F.; Lawes, M.J.; Letcher, S. G.; Lindsell, J.; Lovett, J.; Lozada, J.; Lu, X.; Lykke, A.M.; Mahmud, K. Bin; Mahayani, N.P.D.; Mansor, A.; Marshall, A.R.; Martin, E.H.; Calderado Leal Matos, D.; Meave, J.A.; Melo, F.P.L.; Mendoza, Z.H.A.; Metali, F.; Medjibe, V. P.; Metzger, J.P.; Metzker, T.; Mohandass, D.; Munguía-Rosas, M.A.; Muñoz, R.; Nurtjahy, E.; de Oliveira, E.L.; Onrizal; Parolin, P.; Parren, M.; Parthasarathy, N.; Paudel, E.; Perez, R.; Pérez-García, E.A.; Pommer, U.; Poorter, L.; Qi, L.; Piedade, M.T.F.; Pinto, J.R.R.; Poulsen, A.D.; Poulsen, J.R.; Powers, J.S.; Prasad, R.C.; Puyravaud, J.-P.; Rangel, O.; Reitsma, J.; Rocha, D.S.B.; Rolim, S.; Rovero, F.; Rozak, A.; Ruokolainen, K.; Rutishauser, E.; Rutten, G.; Mohd. Said, M.N.; Saiter, F.Z.; Saner, P.; Santos, B.; dos Santos, J.R.; Sarker, S.K.; Schmitt, C.B.; Schoengart, J.; Schulze, M.; Sheil, D.; Sist, P.; Souza, A.F.; Spironello, W.R.; Sposito, T.; Steinmetz, R.; Stevart, T.; Suganuma, M.S.; Sukri, R.; Sultana, A.; Sukumar, R.; Sunderland, T.; Supriyadi; Suresh, H.S.; Suzuki, E.; Tabarelli, M.; Tang, J.; Tanner, E.V.J.; Targhetta, N.; Theilade, I.; Thomas, D.; Timberlake, J.; de Morisson Valeriano, M.; van Valkenburg, J.; Van Do, T.; Van Sam, H.; Vandermeer, J.H.; Verbeeck, H.; Vetaas, O.R.; Adekunle, V.; Vieira, S.A.; Webb, C.O.; Webb, E.L.; Whitfeld, T.; Wich, S.; Williams, J.; Wiser, S.; Wittmann, F.; Yang, X.; Adou Yao, C.Y.; Yap, S.L.; Zahawi, R.A.; Zakaria, R.; 
610

611

612

613

614

615

616

617

618

619

620

621

622

623

624

625

626

627

628

629

630

631

632

Zang, R. Phylogenetic classification of the world's tropical forests. Proc. Natl. Acad. Sci. 2018, 115, 1837-1842, doi:10.1073/pnas.1714977115.

66. Aguilar-Romero, R.; Pineda-García, F.; Paz, H.; González-Rodríguez, A.; Oyama, K. Differentiation in the water-use strategies among oak species from central Mexico. Tree Physiol. 2017, 37, 915-925, doi:10.1093/treephys/tpx033.

67. Venegas-González, A.; von Arx, G.; Chagas, M.P.; Filho, M.T. Plasticity in xylem anatomical traits of two tropical species in response to intra-seasonal climate variability. Trees - Struct. Funct. 2015, 29, 423-435, doi:10.1007/s00468-0141121-z.

68. Mamatha, B.S.; Sujatha, D.; Nath, S.K.; Uday, D.N.; Nandanwar, A. Development of fire retardant wood composite using amino resin; In Wood is Good, Pandey, K., Ramakantha, V., Chauhan, S., Arun Kumar, A. Springer, Singapor, 2017; pp. 353361; ISBN 978-981-10-3113-7.

69. Bayramzadeh, V.; Funada, R.; Kubo, T. Relationships between vessel element anatomy and physiological as well as morphological traits of leaves in Fagus crenata seedlings originating from different provenances. Trees - Struct. Funct. 2008, 22, 217-224, doi:10.1007/s00468-007-0178-3.

70. Rita, A.; Borghetti, M.; Todaro, L.; Saracino, A. Interpreting the climatic effects on xylem functional traits in two Mediterranean oak species: The role of extreme climatic events. Front. Plant Sci. 2016, 7, 1-11, doi:10.3389/fpls.2016.01126.

71. Hacke, U.G.; Sperry, J.S. Functional and ecological xylem anatomy: Perspectives in plant ecology, evolution and systematics; Springer Cham., London, 2001; pp. 97115; ISBN 978-3-319-15782-5. 
633 72. Steppe, K.; Lemeur, R. Effects of ring-porous and diffuse-porous stem wood

634 anatomy on the hydraulic parameters used in a water flow and storage model. Tree

635 Physiol. 2007, 27, 43-52, doi:10.1093/treephys/27.1.43.

636 73. Aguilar-Romero, R.; Pineda-Garcia, F.; Paz, H.; González-Rodríguez, A.; Oyama, 637 K. Differentiation in the water-use strategies among oak species from central

638 Mexico. Tree Physiol. 2017, 37, 915-925, doi:10.1093/treephys/tpx033.

639

640 


\section{Table 1}

642 Growth rings statistics for Magnolia vovidesii and M. schiedeana at the two study sites in

643 the mountains of the Sierra Madre Oriental of eastern Mexico.

644

\begin{tabular}{lcc}
\hline Statistics & Magnolia vovidesii & Magnolia schiedeana \\
\hline Sampled trees & 20 & 20 \\
Cross-dated series $^{\mathrm{a}}$ & 25 & 32 \\
Master series (year) & $1941-2016$ & $1697-2016$ \\
Cross-dated rings $^{\mathrm{a}}$ & 2545 & 2101 \\
Series intercorrelation $^{\mathrm{b}}$ & 0.501 & 0.785 \\
Mean sensitivity $^{\mathrm{a}}$ & 0.288 & 0.304 \\
Autocorrelation $^{\mathrm{a}}$ & 0.501 & 0.532 \\
Mean/median age (years) & $75 / 50$ & $316 / 201$ \\
Common interval $^{\text {Signal-to-noise }}{ }^{\mathrm{c}}$ & $1938-2016$ & $1798-2016$ \\
\hline
\end{tabular}

${ }^{a}$ Values obtained with COFECHA [42]

${ }^{b}$ Values statistically different using Mann-Whitney test $(\mathrm{P}=0.05)$

'Values obtained with ARSTAN [50] 


\section{Figure legends}

652 Figure 1. Map showing the location (A) of the tree-ring sampling sites: El Batda and

653 Medio Monte, located in eastern Mexico; (B) climatic diagrams of Huayacocotla, Veracruz 654 (period $1961-2016 ; 20.5^{\circ} \mathrm{N},-98.5^{\circ} \mathrm{W} ; 2168 \mathrm{~m}$. a.s.1.) and Tenango de Doria, Hidalgo 655 (period $1941-2016 ; 20.3^{\circ} \mathrm{N},-98.2^{\circ} \mathrm{W} ; 1691 \mathrm{~m}$. a.s.1.) weather stations; and (C) view of 656 Magnolia species sampled.

657

Figure 2. Ring-width chronologies of Magnolia vovidessi and M. schiedeana. Micro659 660 sections of the representative wood-core digital images showing annual tree rings and vessels. * Represents the drought year of $1976 . \mathrm{A}=$ M. vovidesii; and $\mathrm{B}=$ M. schiedeana

Figure 3. Correlations between chronologies against the mean maximum, mean minimum temperatures $\left(\mathrm{T}_{\max }, \mathrm{T}_{\min }\right)$ and monthly precipitation $(\mathrm{P})$ for each drought year (September to September) from the year 1941 onward. Lines indicate positive and negative correlations with a $95 \%$ confidence.

666

667

Figure 4. Violin plots showing differences in vessel traits between DY and NDY for both 668 Magnolia species studied: For drought (DY) and non-drought (NDY) years: A= vessel

669 frequency; $\mathrm{B}=$ vessel diameter; and $\mathrm{C}=$ vessel length.

670

671

672

673 


\section{$674 \quad$ Figure 1}
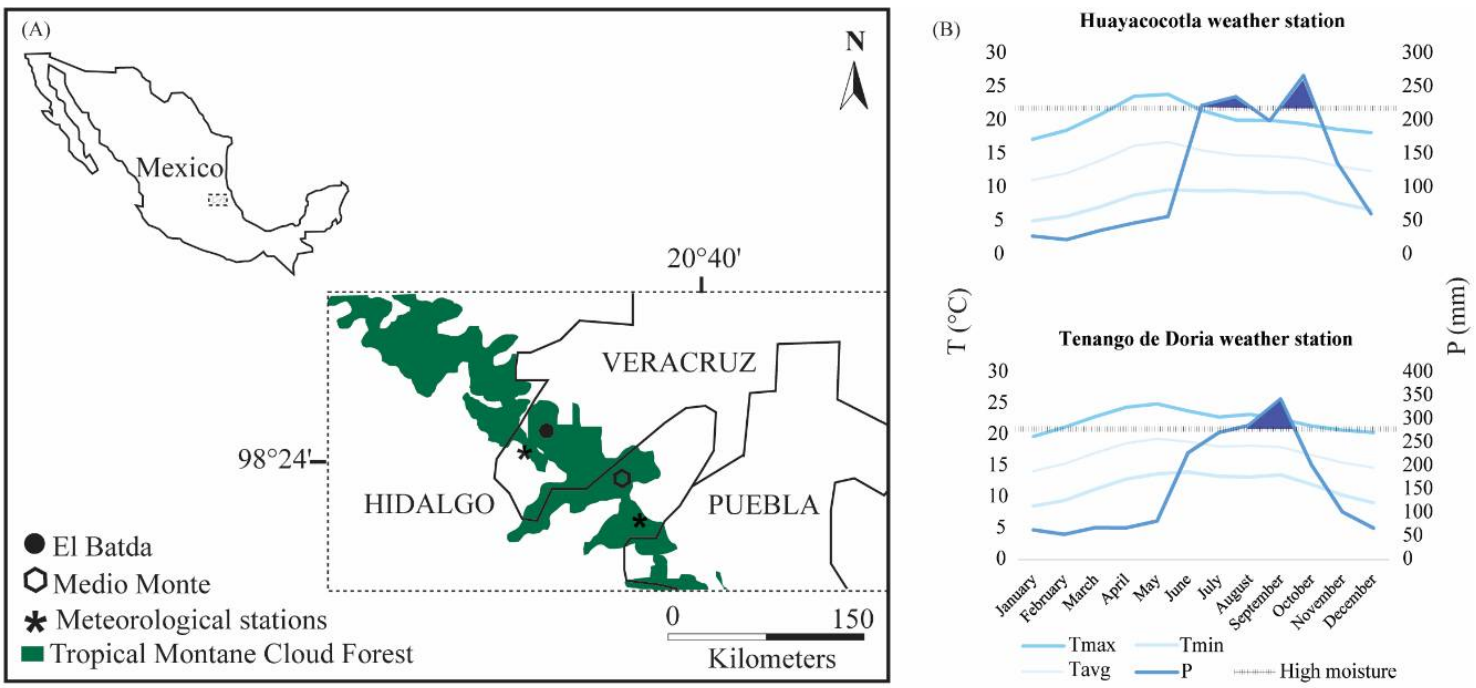

(C)
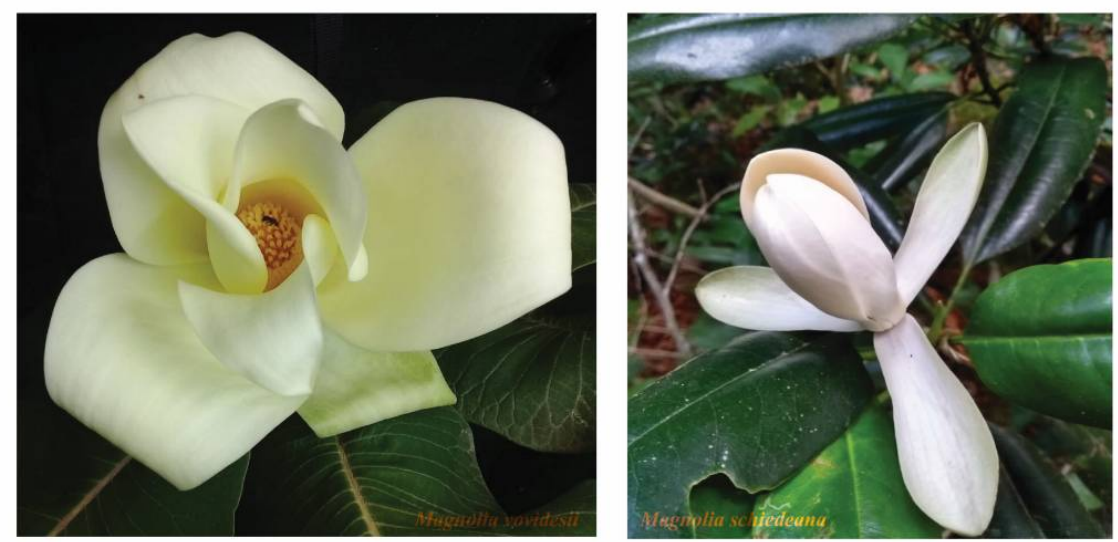

675

676 


\section{$677 \quad$ Figure 2}

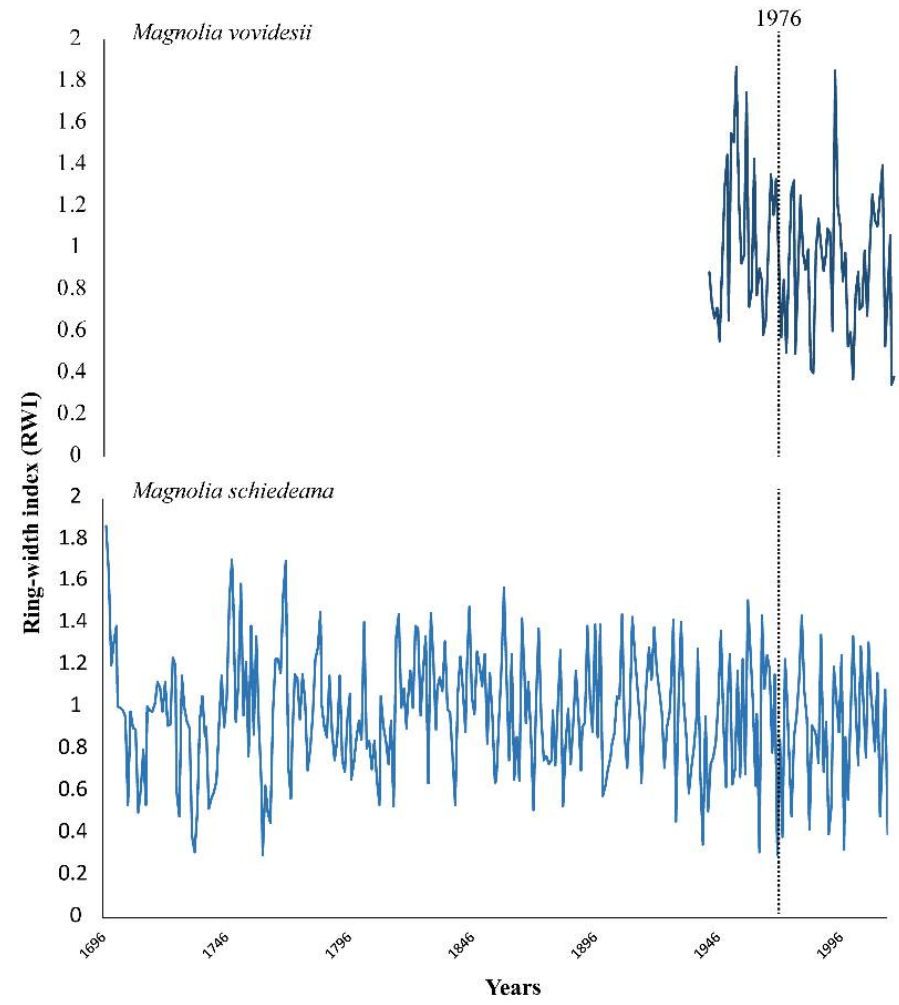

(A)

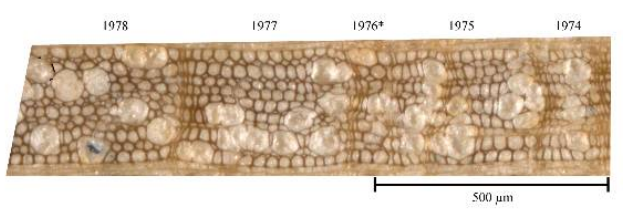

(B)

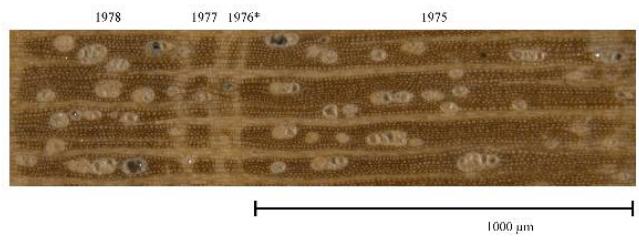


$680 \quad$ Figure 3

681

682

683

684

685

686

687

688

689

690

691

692

693

694

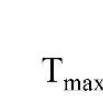

0.5

- Magnolia vovidesii

- Magnolia schiedeana

0.4
0.3

0.2
0.1

0.1
0

0
-0.1
-0.2
-0.3
-0.4
-0.5

$\mathrm{T}_{\min }$

0.2

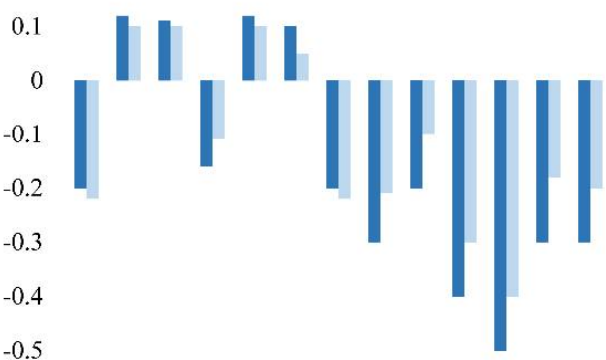

$-0.5$

$-0.6$

$\mathrm{P}_{\mathrm{rec}}$

695

696

697

698

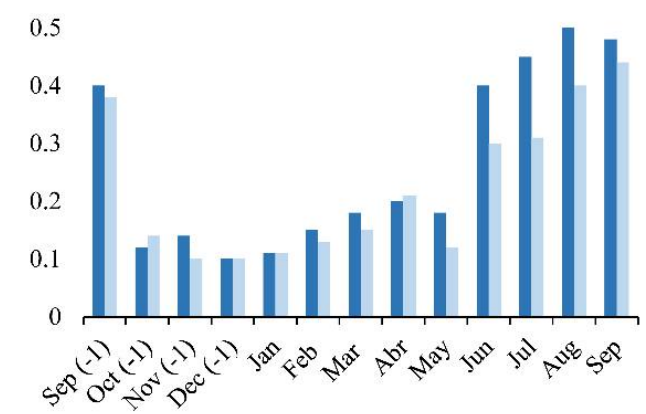

699 
$700 \quad$ Figure 4

701

702
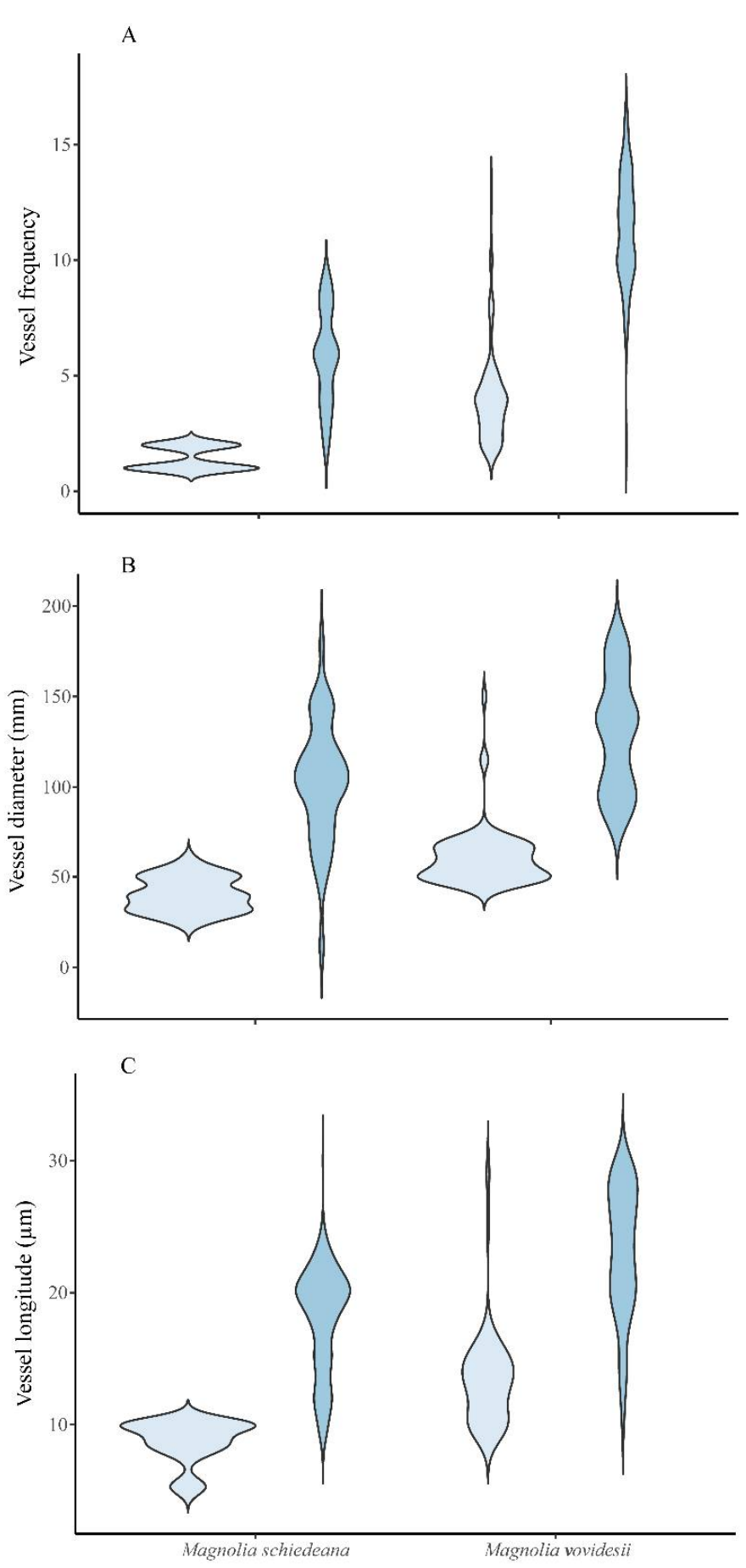